\title{
Data Processing for Global Environmental Research
}

\author{
Ryutaro TATEISHI ${ }^{*}$ and Koji KAJIWARA**
}

\begin{abstract}
The recent recognition of the importance of global environmental research brings researchers on remote sensing and geographic information systems (GIS), to fulfill the urgent needs to establish global databases, algorithm of data processing for globally covered data, and global GIS. This paper clarifies the steps of global environmental research and identifies what needs to be done for successful data processing of global data.
\end{abstract}

\section{Introduction}

It is well known that human activity has contributed to significant global environmental changes within the last several decades. The critical necessity of global environmental research has been widely recognized and its importance has been described in many symposia and papers. Then the production of globally covered environmental data has been considered as the most important job for global environmental researches, and scientists have noticed that environmental research can be carried out only by the objective analysis of the global environmental data. Therefore it can be said that the successful global environmental researches depend on the achievement of the research on data production, database, and data processing functions of global data.

\section{Steps of Global Environmental Research}

There are four steps of global environmental research.

1) Estimate of the present situation and changes of global environmental factors

Environmental factors can be divided into physical and social factors. Table 1 shows the examples of environmental factors. Geographical or spatial distribution and temporal change of environmental factors are the basic knowledge for global environmental research. Therefore global data of environmental factors should have sufficient geographical or spatial resolution and temporal resolution.

2) Understanding of the relation and interaction among global environmental factors

The research to investigate the relation and interaction among global environmental factors including social factors, which describe human activities, is important in order to understand the mechanism of global environment. The earth system science proposed by National Aeronautics and Space Administration (NASA), the United States in 1983 has the same purpose as this step of global environmental research.

The research to investigate the relation and interaction among the entire environmental factors is a very complicated task. The long-

\footnotetext{
* Remote Sensing and Image Research Center, Chiba University (1-33 Yayoi-cho Inage-ku, Chiba 263 Japan)
} 
Table 1 Environmental factors

\begin{tabular}{l|l|l}
\hline \hline \multicolumn{2}{c|}{ Category } & \multicolumn{1}{|c}{ Examples of factors } \\
\hline \multirow{4}{*}{ Physical } & Terrestrial & $\begin{array}{l}\text { DEM } \\
\text { Land cover } \\
\text { Soil type }\end{array}$ \\
\cline { 2 - 3 } & Meteorological & $\begin{array}{l}\text { Temperature } \\
\text { Precipitation } \\
\text { Evapotranspiration }\end{array}$ \\
\cline { 2 - 4 } Social & Atmospheric & $\begin{array}{l}\mathrm{CO}_{2} \text { density } \\
\mathrm{O}_{3} \text { density }\end{array}$ \\
\cline { 2 - 4 } & Oceanographic & $\begin{array}{l}\text { Sea surface temperature } \\
\text { Chrolophyl density }\end{array}$ \\
\hline & $\begin{array}{l}\text { Population } \\
\text { Industry } \\
\text { Water use } \\
\text { Land use }\end{array}$ \\
\hline
\end{tabular}

term earth observations and cooperation among researchers of various academic fields are indispensable to pursue this goal. Therefore it is practical to begin with the research of investigating the relation and interaction among limited number of environmental factors such as forest area and $\mathrm{CO}_{2}$, or water resource and human activities.

\section{3) Forecast and simulation of global envi- ronmental factors}

A model of the mechanism of global environment can be established through the knowledge about interaction among environmental factors in the previous step. Based on the established model, a certain environmental factor can be simulated by the assumption of other environmental factors. For example, $\mathrm{CO}_{2}$ density may be simulated by the assumption of forest cutting and industrial growth, or the balance of water resource may be simulated by the assumption of the increase of irrigation, industrial water use and human population.

\section{4) Sustainable solution of human activities}

It is the final goal to find the way to keep sustainable environment. In other words, this step is to find what human activities should be restricted or recommended under the condition of keeping environmental factors within a sustainable level. For example, sustainable land use in global scale may be recommended, or a certain industry may be restricted.

The first step is a basic part of global environmental research. The production of global data of environmental factors is the initial task for the research. The second step is the most difficult part of the research. Perhaps it is impossible to understand the relation and interaction among the entire environmental factors quantitatively and completely within a few decade. Therefore we must proceed to the next step with a limited knowledge about the results of the second step of the research, because we need to know the results of the final step as early as possible to keep environmental factors within a sustainable level. 


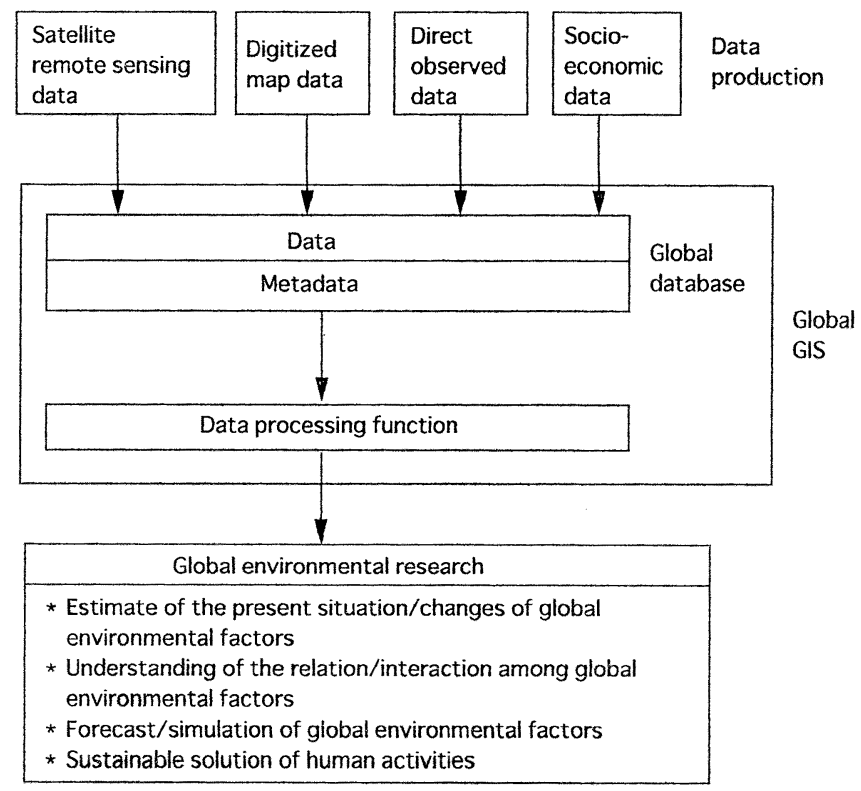

Fig. 1 Data production, global database and global GIS for global environmental researches

\section{Global Data}

As stated in the introduction, global data play a main role in global environmental research. This section describes about global data production, global database and global GIS.

\section{1) Global data production}

There are four types of global data from the view point of their data source as shown in Figure 1. They are satellite remote sensing data, digitized map data, direct observed data and socio-economic data. An example of satellite remote sensing data is NOAA AVHRR data which can provide globally covered 1.1 $\mathrm{km}$ Normalized Difference Vegetation Index (NDVI) (Townshend, 1992). Another main source of global data is topographic or thematic maps. For example, global digital elevation model (DEM), ETOPO 5, by National Geophysical Data Center (NGDC), the United States was produced by digitizing topographic maps. A typical example of direct observed data is meteorological data such as temperature and precipitation. The most of direct observed data are given at irregularly located points. Therefore the interpolation is an important step of processing for this type of data. The socioeconomic data such as population and industrial water use are collected through census or survey. The most of the socio-economic data are given according to political units. Therefore more fine resolution data are frequently requested for environmental research.

\section{2) Global database/GIS}

After various global data are produced, they must be stored and managed as global database for the subsequent data processing. And the global database should include data about data, $i$. e. metadata. The existing global databases are reviewed in the section 4 . The processing of globally covered data needs some new functions. The data processing system including the new functions with global database is called global GIS. Figure 1 shows the concept of 
global data processing with global database/ GIS. Global GIS can accelerate the global environmental research because of its efficient processing of global data. Many researchers have recognized the necessity of global GIS (Steyaert, 1989; Maguire, 1991; Wheeler, 1992). However there is no global GIS which can be used practically. What needs to be done for the production of better global database and establishing global GIS is explained in the section 5 .

\section{Existing Global Databases}

The following global databases are available at present.

1) Global Ecosystems Database DISC-A on CD-ROM (Kineman and Ohrenschall, 1992) (DISC-B will be available in 1993)

This database was produced by National Oceanic and Atmospheric Administration (NOAA)/National Geophysical Data Center (NGDC) in cooperation with U. S. Environmental Protection Agency (EPA). It includes 16 datasets of Global Vegetation Index (GVI), temperature, precipitation, land cover, soil, elevation, etc. 15 datasets of them are raster data in latitude/longitude. One dataset is vector data.

\section{2) Global GRASS 1,2 and 3 CD-ROM datasets}

These datasets were produced by Cook College Remote Sensing Center of Rutgers University in cooperation with the U. S. Army Corps of Engineers Construction Engineering Research Laboratory (USA/CERL). They include elevation, vegetation type, national boundaries, soil characteristics, marine production, watersheds, river, etc. Most of them are raster data in latitude/longitude.

\section{3) GRID global datasets}

These datasets were produced by Global Re- source Information Database (GRID) of Global Environmental Monitoring System (GEMS) of United Nations Environmental Programme (UNEP). They include political boundaries, elevation, soil, vegetation, population, cultivation, ecosystems, etc. Most of them are based on raster in latitude/longitude.

\section{4) Digital Chart of the World}

This was produced by the United States Defense Mapping Agency in cooperation with the military map producers of Canada, Australia, and the United Kingdom. The database contains major road and rail networks, major drainage systems, major utility networks, all major airports, contours, coastlines, international boundaries and populated places. The data is stored in the vector format.

\section{5) World Data Bank II}

This was produced by the United States Central Intelligence Agency (CIA). It contains coastal lines, international boundaries, lakes, islands. The data is vector type.

Other global data are available through World Data Center (WDC), National Space Science Data Center (NSSDC) of NASA, the U. S., National Environmental Satellite Data and Information Service (NESDIS) of NOAA, the U. S., and World Meteorological Organization (WMO).

One common characteristic of the above databases is that all raster data are based on latitude/longitude. The other characteristics are that these databases are actually just datasets and no data processing function is included. However the database 1) is designed to be used by GIS software, IDRISI of Clark University, USA, the database 2) is designed for GIS software, GRASS of USA/CERL, and the database 4) is designed for ARC/INFO. 


\section{Requirements for Global Data Proc- essing}

In this section, the requirements for successful global data processing are identified for data production, global database and global data processing functions.

\section{1) Data production}

a. Preprocessing of globally covered remote sensing data

Radiometric correction of remote sensing data is not a new subject. Production of globally covered satellite remote sensing data, however, revealed new radiometric problems. One significant problem is atmospheric correction, mainly aerosol correction. The radiometric distortion of the global image by atmosphere is mainly caused by the change of the solar zenith angle and off-nadir observation angle and partly by the global coverage which includes various atmospheric conditions. There has been some research on atmospheric correction (Matsumoto et al., 1991; Teillet, 1992) but further study is necessary. Another problem in radiometric distortion is caused by the difference of bidirectional reflectance distribution function (BRDF) of various landcovers. This problem is emphasized by a large off-nadir observation angle.

Geometric preprocessing is the other important subject. Most of the globally covered remote sensing data are geocoded on latitude/ longitude coordinate system. However the pixels on latitude/longitude do not represent area of equal size at the surface. The suitable data structure, or map coordinate, should be selected or developed. The description about data structure is given in 2) b. of this section.

b. Interpolation of direct observed data

Meteorological measued data on the ground tends to be geographically located sparsely in deserts or barren areas. Simple interpolation method can not work well for sparsely distributed meteorological data. A new interpolation method should be developed by using satellite data as secondary observed data or using other information such as landcover or digital elevation model (DEM), which explains non uniformity of the geographical trend of meteorological data.

\section{c. Map digitization}

The existing vector data are not necessarily well designed for their usage. For example, the vector data of river locations do not include the attribute data of the direction of the flow which is important for the analysis of water resources. Therefore digitized map data should be produced to meet the requirements for their usage.

2) Global database

a. Data inquiry system and metadata

The first step of global data processing is to inquire about the data. The establishment of easily accessible data inquiry systems will accelerate the successful global data processing. Data inquiry system through network should give the information of data availability, how to order the data and the content of metadata. Metadata is data about data which includes data content, definition of categorized data, accuracy /quality of data, history of data, comments of the data by users, etc.

b. Data structure

The key subject to establish global database is a well designed data structure. The desirable data structure has the following features.

1. Capability of processing beyond the edge of a map

2. Capability of processing with adjoining pixels

3. Equal area

4. Capability of storing data with different 
resolution

5. Storing multitemporal data

6. Storing $3 \mathrm{D}$ data

7. Ease to display on the raster type image output device

8. Ease to resample voluminous remote sensing data into the proposed data structure

There is no data structure which satisfies all the above requirements. The solution lies on the best compromise among the above requirements.

\section{3) Data processing functions}

a. Data integration

When a certain environmental factor is estimated from other environmental factors, the data of these factors must be geographically registered and correspond temporally. This spatial and temporal data integration is also necessary when the relations and interactions among some environmental factors are investigated. The data integration is performed by transforming data types between raster and vector, by transforming map projection, by changing geometrical resolution by averaging or interpolation, and by interpolating temporal data. The function to enable various types of data integration must be prepared.

b. Estimate of accuracy/quality

In the global environmental research, various types of data from various sources are used. Since accuracy/quality of each data varies widely, the reliability of the results from processing using a number of global data should be evaluated. First, accuracy/quality of the data should be described in the metadata (Tateishi, 1993). Secondly, the theory to estimate accuracy/quality through various types of data processing must be established.

c. Temporal processing

New functions of temporal processing is necessary for the efficient processing. This includ- es dataset management of temporal datasets, efficient browsing of temporal data with visualization capability, efficient command capability by which one operation works to all temporal datasets, etc. Beller et al. (1991) has proposed a prototype of software for temporal processing.

d. Visualization

The visualization of spherical data of the entire earth, temporal data, and $3 \mathrm{D}$ data such as oceanic data and atmospheric data is necessary as human interface. It must contain interactive functions and animation.

e. Utilization of the existing data processing systems

Global data processing needs a number of data processing functions in the existing image processing systems, geographic information systems and statistical processing systems. It is an useless efforts to develop the same softwares or functions as the existing one. Therefore we should make good use of the existing data processing systems. For example, the software of map projection transformation is included in the existing GIS. In order to utilize the existing data processing systems, the function to change the data structure/format to and from the major data processing system is necessary.

\section{Conclusion}

The objectives and steps of global environmental researches are clarified and the requirement for global data processing are identified. The global data production and the establishment of global GIS including network inquiry system, global database and new data processing functions will highly help the global environmental researches. It is, however, a diffcult task to produce the entire global data and to establish global GIS by the effort of an individual researcher. The cooperation of a 
number of researchers is necessary to work out a successful global data processing procedure. Through such joint efforts, global environmental researches will be more accelerated.

\section{References}

Beller, A., Giglin, K. L., Litz, S., Kittel, T. and Schimel, D. (1991): A temporal GIS prototype for global change research. Proceedings of GIS/LIS, Atlanta.

Kineman, J. J. and Ohrenschall, M. A. (1992): Global ecosystems databases version 1.0: $\operatorname{disc} A$, Documentation manual. Key to Geophysical Records Documentation No. 27. USDOC/NOAA National Geophysical Data Center, Boulder, CO. 240 p.

Maguire, D. J. (1991): Geographical Information Systems. Longman Scientific \& Technical, 2, 217231.

Matsumoto, M., Odajima, T., Kajiwara, K. and Tateishi, R. (1991): Solar zenith angle dependence of NOAA GVI data and its correction. (in Japa- nese) J. Japan Society of Photogrammetry and Remote Sensing, 30-3, 34-41.

Steyaert, Louis T. (1989): Investigating the use of geographic information systems technology in the computer workstation environment for global change research. Proceedings of ASPRS/ACSM, 4, 46-54.

Tateishi, R. (1993): Recording accuracies in global land surface datasets. J. Geography, 102, 234240.

Teillet, P. M. (1992): An algorithm for the radiometric and atmospheric correction of AVHRR data on solar reflective channels. Remote Sensing of Environment, 41, 185-195.

Townshend, John R. G. (1992): Improved global data for land applications. IGBP Global Change Report No. 20, p. 87.

Wheeler, Douglas J. (1992): The coupling of GIS and environmental process models in global change research: Where do we go from here? Proceedings of ASPRS, 244-253.

(Received 18. May 1993, Accepted 14. June 1993)

\section{地球環境研究のためのデータ処理}

\section{建石隆太郎* 梶原 康司*}

地球環境に関する研究の重要性は今や十分に認 識されている。この認識のもとにリモートセンシ ングおよび地理情報システム（GIS）の研究者の 間では, 各種環境要素を記述したグローバルなデ ータベースの整備, グローバルデータ特有のデー

\footnotetext{
* 千葉大学映像隔測研究センター
}

夕処理手法の開発，グローバルデータを扱ら地球 環境研究のための GIS の構築, の必要性が認識 され始め，一部実行に移されている。本論文で は，地球環境研究のステップを明確にし，これを 遂行するためのグローバルデータの処理の研究と して何をなすべきかについて述べている。 